\title{
Arbeidsinnkludering som en vei til varig arbeidslivstilknytning og et verdig voksenliv: Hvordan metoder for arbeidsinnkludering kan brukes i opplæringen av lærekandidater
}

(Work inclusion as a way to a lasting working life connection and a dignified adult life: How methods for work inclusion can be used in the training of apprentice candidates)

\section{Eva Martinsen Dyrnes \& Dan Roger Sträng}

Høgskolen i Østfold, Norge (eva.m.dyrnes@hiof.no)

\section{Abstract}

The labour market in many European countries is changing and for many young people it leads to challenges in gaining a lasting connection to working life.

School dropout and deficiencies in their education lead to challenges for many young people on the road to adulthood. Students who find it difficult to complete a vocational education in upper secondary school, now have the opportunity to be training candidates in a practically oriented education with a limited number of competence goals.

Work inclusion means that the individual's ability to work will be examined in various ways to increase the possibility of permanent work. However, work inclusion is a complex phenomenon, where several actors may be involved and where the goals and progress plan will vary. This is costly and stressful for both the individual and the society. Working life is a central learning arena within upper secondary education, and there will be a need to facilitate participation in this arena also for students with a need for adapted education.

Keywords: worthy adulthood, training candidate, work inclusion, vocational education 


\title{
Globale endringer i arbeidslivet
}

I motsetning til de i fleste andre europeiske land, har det norske arbeidsmarkedet fram til dagens situasjon, som følge av koronapandemien, i flere år vært relativt stabilt, med lav arbeidsløshet og gode arbeidsmuligheter (NOU 2012:6). Demografiske endringer og en voksende og samtidig aldrende befolkning, samt økt press på helse- og velferdstjenestene framstår imidlertid som nye utfordringer. Den totale andelen sysselsatte har i de seinere årene minsket og et stadig voksende utenforskap blant unge, har gjort at flere enn tidligere av helsemessige og andre årsaker risikerer å havne utenfor arbeidsmarkedet (Mandal et al., 2019).

I Statens Arbeidsmiljøinstitutts årsrapport for 2016 fastslås det at norsk arbeidsliv i en periode med stor teknologisk utvikling opplever store muligheter knyttet til digitalisering, automatisering, nye materialer og bioteknologi. Samtidig står Norge midt i et grønt skifte, med utfordringer når det gjelder høy yrkesdeltakelse og forlengede yrkeskarrierer (Statens arbeidsmiljøinstitutt, 2016).

Pajarinen et al. (2015) påpeker at det norske arbeidsmarkedet kan forvente store endringer i yrkesstrukturen, der yrker som f.eks. butikkmedarbeider, sekretær, bankfunksjonær og kontoransatt i stor grad kan bli automatisert. Andre yrkesgrupper som f.eks. sykepleiere og ansatte i barne-, oppvekst- og omsorgssektoren, ser i mindre grad ut til å påvirkes av dette (Pajarinen et al., 2015).

Dette er utfordringer som arbeidsinkluderingspolitikken må møte.

\begin{abstract}
Med arbeidsinkluderingspolitikken menes her innsats for å få utsatte grupper, særlig personer med nedsatt arbeidsevne, over $i$ arbeid og arbeidsrettet aktivitet. God nyttiggjøring av arbeidskraften blir særlig viktig for å opprettholde velferdssamfunnet etter hvert som andelen av befolkningen i yrkesaktiv alder avtar. (NOU 2012:6)
\end{abstract}

På et globalt plan fører digitalisering og automatisering til at mange av dagens yrker erstattes av ny teknologi og forsvinner. I flere europeiske land har man regnet ut at opptil halvparten av jobbene kan være i risikosonen (Berger \& Frey, 2016). Samtidig oppstår nye arbeidsmuligheter med krav til ny kunnskap og kompetanse i et livslangt læringsperspektiv. Ifølge World Economic Forum kan det handle om en nettovekst i antall jobber (Schwab, 2018). En forutsetting er at virksomheter, individer og myndigheter vektlegger livslang læring (NOU 2019:12). Å utrede og utvikle nye samarbeidsformer mellom skole og arbeidsliv er her en viktig og grunnleggende suksessfaktor.

Som et ledd i arbeidet med å møte endringer i arbeidsmarkedet, oppnevnte Regjeringen i 2018 et ekspertutvalg som skulle vurdere behovet for etter- og videreutdanning i befolkningen, og utdanningssystemets evne til å imøtekomme dette. Det skulle også ses på om rammebetingelsene for investering $\mathrm{i}$ kompetanse var tilstrekkelig gode. Oppdraget gikk også ut på å utarbeide et kunnskapsgrunnlag for å danne grunnlag for vurderinger og forslag til tiltak (Kompetanse Norge, u.å.). 
I utvalgets sluttrapport til Regjeringen (NOU 2019:12) slås det fast at det å legge til rette for livslang læring er mer aktuelt enn tidligere. Det mangler imidlertid kunnskap om hva begrepet står for og hvordan det skal implementeres i det norske utdanningsløpet.

\begin{abstract}
Neste skritt er å gå fra et system der vi primært lærer først og jobber etterpå, til et system der vi lærer hele livet og jobber underveis. Dette er en naturlig konsekvens av en stadig mer omfattende akkumulering av kunnskap og økte behov for raskere endringer på mange områder. Å nå kunnskapsfronten er stadig mer krevende, og den omfattende satsingen på forskning og innovasjon gjør at det ikke er tilstrekkelig å utdanne seg "en gang for alle". (NOU 2019:12)
\end{abstract}

Utvalget mener videre at kompetanseheving og kvalifisering er et velegnet virkemiddel i arbeidsmarkedet som vil få økende betydning, gitt at det dekker markedets behov og krav. Videregående opplæring har en viktig rolle i et system for livslang læring, men er en ressurs som er lite utnyttet som tilbyder inn mot næringslivet. Opplærings- og utdanningstilbudet i videregående opplæring vil kunne dekke et behov i mange virksomheter og dermed bidra til arbeidsinnkludering (NOU 2019:12).

Med dette bakteppet har vi i en empirisk studie undersøkt hvordan metoder for arbeidsinnkludering kan brukes i overgangen fra videregående opplæring til varig arbeidslivstilknytning. Vi ser spesielt på lærekandidatordningen som omtales seinere.

\title{
Arbeidsinnkludering
}

Bruk av bestyrkende faktorer er et perspektiv i arbeidet med å forbygge frafall i videregående utdanning. Det kan videre legge til rette for, og fremme varig arbeidslivstilknytning (Breilid \& Dyrnes, 2017). Dette kan ses som en innfallsvinkel til begrepet arbeidsinnkludering som er relativt nytt i Norge. Det handler om at alle har en arbeidsevne som kan brukes og utvikles med riktig oppfølging, samt at de aller fleste er motivert for å delta i arbeidslivet. Arbeidstrening og opplæring i det ordinære arbeidslivet skal være førstevalget for alle og både arbeidsgiver og arbeidstaker må få den bistanden som skal til for å etablere og opprettholde arbeidsforhold (Breilid \& Dyrnes, 2017).

Ifølge Åsheim (2019) er arbeidsinnkludering å undersøke en persons evne til å arbeide ved å prøve ut ulike typer arbeid, kurs eller utdanning som øker kvalifikasjonene. Denne prosessen kan gå over mange år, og kan oppleves som mer eller mindre målrettet. Utfallet av en arbeidsavklaringsprosess er ikke bare økonomisk, men tilknytningen til en arbeidsplass vil gi den enkelte tilgang til både fellesskap med andre og en mestringsarena (Strand \& Nielsen, 2015; Tøssebro \& Wik, 2013; Åsheim, 2018). 
I en rapport fra forskningsprosjektet "Arbeidsinnkludering - med arbeidsgiverne på laget" (Mandal et al., 2019) gis begrepet arbeidsinnkludering følgende innhold:

\begin{abstract}
Arbeidsinnkludering er et vidt begrep, og vi forstår at det for NAV og brukerne handler om to ting; for det første ordinært arbeidsliv som arena for kvalifisering, arbeidsutprøving og avklaring; for det andre målet om ansettelse [...]. Ofte er det naturlig å se de to målene i sammenheng, siden hovedmålet med å bruke ordinært arbeidsliv som utprøvingsarena ofte er ansettelse og varig tilknytning til arbeidslivet. (Mandal et al., 2019, s. 15)
\end{abstract}

Breilid og Dyrnes (2017) identifiserte faktorer som så ut til å bidra til å styrke yrkesfagelevenes mestring i overgangen fra videregående skole til arbeidslivet. Faktorer som at lovgrunnlaget for virksomheten er av inkluderende natur og at det er et godt støtteapparat og samarbeid med en helhetlig tilnærming rundt eleven ser ut til å være av betydning. I tillegg til dette er tett individuell tilpassing, og tilrettelegging med mulighet for egen medvirkning og tidlig intervensjon av betydning i denne sammenhengen (Sletten \& Hyggen, 2013). Dette er faktorer som i seg selv er med på å bidra i arbeidet med å legge til rette for arbeidsinnkludering. Ikke minst vil lovgrunnlaget være gjenstand for tolkning og dermed utvikling av ulike praksiser hos aktørene og instansene som elevene er i kontakt med.

Bonoli (2010) identifiserer fire ulike aktiviseringsstrategier: forsterkning av insentiver, arbeidsstøtte eller jobbassistanse, arbeidsrettede kurs og videre kvalifisering. Eide et al. (2017) mener at flere parallelle strategier kan avdekkes i ulike tiltak (Bonoli, 2010; Schøyen, 2016).

Modellen for arbeidsinnkludering som vi refererer til i vår studie, er en integrert metodikk med flere parallelle strategier, der kartlegging, opplæring, veiledning og tilrettelegging foregår på eller i nær tilknytning til en reel arbeidsplass. Kompetanse i jobbsammenheng er knyttet til å utføre arbeidsoppgaver og til det å delta i et arbeidsfellesskap. Arbeidsevnen for den enkelte deltaker ligger derfor i skjæringspunktet mellom den enkelte deltakers muligheter og begrensinger sett i forhold til krav og forventninger ved den enkelte arbeidsplass.

En del av løsningen for deltakerne blir dermed å legge til rette slik at vedkommende ikke nødvendigvis kan alt, men kan delta med sine begrensinger som følge av sosiale, fysiske, psykiske eller andre utfordringer. Opplæringen til å mestre arbeidsoppgavene skjer på arbeidsplassen i arbeidet med reelle arbeidsoppgaver. Tidlig frafall og mangelfull gjennomføring av utdanning er en utfordring for mange unge på veien mot varig arbeidslivstilknytning, i tillegg til å være en samfunnsaktuell problemstilling. En del unge har svake skoleresultater, mangelfulle grunnleggende ferdigheter og måloppnåelse ved overgangen mellom grunnskole og videregående opplæring. Det innebærer for mange å ha ufullstendige vitnemål med manglende og ofte svake resultater. Dette vil forplante seg inn i videregående opplæring, og mange elever avbryter eller klarer ikke å 
gjennomføre utdanningen (Bakken \& Elstad, 2012; Meld. St. nr. 20 (2012-2013), 2013). Overganger kan være kritiske, og spesielt for personer med ulike behov for tilrettelegging.

Manglende kompetanse er en av de viktigste årsakene til at enkeltpersoner havner utenfor skole og arbeid, noe som igjen kan føre til utenforskap. Dette er kostbart og belastende for både den enkelte og samfunnet. Arbeidslivet er en sentral læringsarena innen videregående opplæring, og det vil være behov for å legge til rette for å delta på denne arenaen også for elever med behov for tilpasset opplæring.

\section{Verdig voksenliv}

Opplevelse av livsmestring, medborgerskap og samfunnsdeltakelse anses som vesentlig for å ha et verdig voksenliv (Utdanningsdirektoratet, 2018). Dette refererer til det å leve et mest mulig selvstendig liv som voksen og å ha tilgang på de goder og rettigheter som er tilgjengelig for enkeltindivider i samfunnet. Det betyr også å være i stand til å ivareta de plikter man har som samfunnsborger. Eksempler på dette kan være å tjene egne penger og ha økonomi og frihet til å bo i egen bolig. I tillegg handler det om å ha størst mulig grad av selvstendighet og meningsfull fritid. I overordnet del av det norske læreplanverket, Fagfornyelsen (Utdanningsdirektoratet, 2018) finner vi de tre tverrfaglige temaene; folkehelse og livsmestring, demokrati og medborgerskap, og bærekraftig utvikling. I yrkesopplæringen skal det legges til rette for at elevenes kompetanse også knyttes til disse temaene ved å arbeide tverrfaglig med ulike faglige problemstillinger med tanke på å utføre yrkesoppgaver og overgangen til varig tilknytning til arbeidslivet.

At denne overgangen blir godt tilrettelagt, er av stor betydning, både med tanke på samfunnsøkonomi, folkehelse og enkeltindividers muligheter til et verdig voksenliv. Det har i tillegg betydning for mulighetene til å få ta del i samfunnets velferdsgoder. I en tid der arbeidsmarkedet rommer færre og kravene til kompetanse stadig er i endring, innebærer dette utfordringer for en del unge på veien ut $i$ arbeidsmarkedet. For ungdom der forholdet til skole og utdanning ikke fungerer optimalt, kan det føre til at enten videregående opplæring ikke fullføres og at studiekompetanse, kompetansebevis eller fagbrev ikke oppnås. Både norsk og internasjonal forskning viser til viktigheten av å være formelt kvalifisert til deltakelse i arbeidslivet ved å ha vitnemål eller kompetansebevis. Uten dette, kan hindringer på veien mot varig arbeidslivstilknytning være spesielt store (NOU 2001: 22; NOU 2018:2; Patzina \& Wydra-Somaggio, 2020). Frøseth (2008) og Markussen (2014) har gjort funn som sammenfaller med dette. De viser til at de som har fullført utdanningsløpet har bedre muligheter i overgangen til varig arbeidslivstilknytning enn de som ikke fullfører. I følge Markussen (2014) er det bedre å 
stryke enn å avslutte utdanningen underveis (Frøseth et al., 2010; Markussen, 2014).

\section{Frafall i videregående opplæring}

Norsk statistikk viser i likhet med statistikk fra andre Skandinaviske land, at mange unge ikke fullfører videregående opplæring (Emblemsvåg, 2020). I Norge sluttet 3,4 \% av alle elever i videregående opplæring i løpet av skoleåret 2018-19, og på yrkesfaglige utdanningsprogram slutter $6 \%$ av elevene (Bakken \& Elstad, 2012). I Norden risikerer mellom 6 og $12 \%$ av de unge og havne i utenforskap over tid. Det kan innebære at de hverken er i skole, arbeid eller arbeidsrettede tiltak (Meld. St. nr. 20 (2012-2013), 2013; Olsen et al., 2016).

I Norge er det 10 yrkesfaglige utdanningsprogram. I de fleste yrkesfag gis opplæringen to år i skole og to år i bedrift. Det er i overgangen mellom andre og tredje året i videregående opplæring at frafallet er størst, og det er i stor grad en utfordring på yrkesfaglige utdanningsprogram der overgangen fra skole til læreplass i bedrift eller virksomhet er mellom andre og tredje året (Frøseth et al., 2010).

Ungdom og unge voksne er en sårbar og utsatt gruppe i dagens arbeidsliv og ifølge statistikk fra Norges Ardeids- og velferdsforvaltning (NAV) for de 10 siste årene er andelen unge uføre fordoblet (StatistiskSentralbyrå, 2019).

Det arbeides mye med å forebygge frafall i videregående opplæring, og eksempler på det kan være tiltak i selve opplæringen og hvordan den kan tilpasses elevenes evner, interesser og behov. I tillegg er det også mye fokus på arbeidet med å legge til rette for gode overganger mellom skole og arbeidsliv med tanke på varig arbeidslivsdeltakelse. Dette begrunnes med at tilknytningen til arbeidslivet er betydelig svakere blant dem som ikke har fullført videregående opplæring (Falch \& Nyhus, 2009). Et eksempel på hvordan dette kan gjøres er å legge til rette for at yrkesfagelever som ikke får vurdering i alle fag eller har svakt karaktergrunnlag, gis mulighet for å gå for planlagt grunnkompetanse og kompetansebevis i stedet for fagbrev. Det innebærer at eleven får en opplæringskontrakt i stedet for lærlingkontrakt med bedriften eller virksomheten, noe som resulterer i et kompetansebevis der lærekandidatens spesifikke kompetanse er beskrevet. Dette kan legge til rette for en overgang til arbeidslivet som ivaretar den enkeltes behov for tilpassing og tilrettelegging av opplæringen.

\section{Lærekandidatordningen}

Ved innføringen av Reform 94 i det norske skoleverket ble også en ny formell kompetanseform, dokumentert delkompetanse, vedtatt. I Opplæringsloven §3 står det: "Den videregående opplæring skal normalt føre fram til studie- 
kompetanse, yrkeskompetanse, dokumentert delkompetanse eller annet ved avsluttet videregående opplæring" (Opplæringslova, 1998).

Lærekandidatordningen ${ }^{1}$ er en parallell og en likeverdig kompetanse til lærlingordningen ${ }^{2}$. Ordningen er ikke definert som spesialundervisning, lærekandidater har imidlertid rett på spesialundervisning i tilfeller der hen ikke har tilfredsstillende utbytte av den ordinære opplæringen. Det skal da på lik linje med praksis i skolen utarbeides en individuell opplæringsplan og på bakgrunn av dette fattes et enkeltvedtak (Opplæringslova, 1998; Utdanningsdirektoratet, 2021a, b). Dette praktiseres svært ulikt i de ulike fylkene i Norge (Markussen et al., 2018, s. 103). Tall fra Utdanningsdirektoratet viser at av 28600 søkere til læreplass i 2019 hadde 3,4 \% fått opplæringskontrakt i desember måned.

Ifølge Markussen (2018) er 79 \% av lærekandidatene i daværende Akershus fylke ${ }^{3}$, som bestod kompetanseprøven i jobb. (70 \% kom i jobb med en gang, og $60 \%$ var i jobb tre år senere.)

Breilid og Dyrnes (2017) finner som sagt i sin undersøkelse blant lærekandidater at bestyrkende faktorer som fremmer en positiv overgang fra skole til varig arbeidslivstilknytning f.eks. kan være at lovgrunnlaget for virksomheten er av inkluderende natur, at opplæringen tilpasses elevenes evner og forutsetninger og ikke minst at elevene har et kompetent sosio-økologiske nettverk. Sett ut fra et bestyrkende perspektiv utledet av begrepet "empowerment" (Lassen \& Breilid, 2012), med utgangspunkt i elevenes forutsetninger med tanke på både interesser, ressurser og erfaringer. Dette er med på å fremme og styrke elevenes muligheter til å ta i bruk og utvikle egne ressurser og til å i større grad ta kontroll over egen tilværelse (Askheim, 2003; Lassen, 2014; Menon, 2001).

Manglende kompetanse er som sagt en faktor som ofte fører til utenforskap for unge mennesker i dag. Siden arbeidslivet er en sentral arena for kompetanseheving, er det interessant å se på hvordan metoder innen arbeidsinnkludering og hvordan disse kan implementeres i arbeidet med å legge til rette for at ungdom fullfører utdanningen og oppnår varig arbeidslivstilknytning.

\section{Metode og gjennomføring}

For å utdype vår kunnskap om fenomenet arbeidsinnkludering valgte vi derfor å gjennomføre en kvalitativ studie, med etnografisk design. Dette ble gjort hos en norsk bedrift som i flere tiår har vært en ledende aktør innen arbeidsinnkludering, med arbeidsrettede tiltak, kompetanseutvikling og andre tjenester til næringslivet.

Hensikten med det empiriske arbeidet var å tolke og analysere arbeidssøkende, NAV veiledere og rådgivere ved arbeidsinnkluderingsbedriften sine handlinger ut ifra deres egne beskrivelser av hverdagen sin gjennom intensjonelle forklaringer (Ronnby, 1983). 
Hilden og Middelthon (2002) framholder at et etnografisk forskningsdesign skaper mulighet for å utforske og teoretisere relevante forhold og fenomener som ikke fanges opp av forhåndsformulerte problemstillinger og spørsmål. Etnografi er en mulighet til å nærme seg sosiale og kulturelle grupper for å skape en ny forståelse av kulturen eller gruppens oppfatning av sin omverden (Alvehus, 2013). Vår studie kan imidlertid ikke på alle måter defineres som etnografi siden vi ikke ønsket å få fram en fullstendig beskrivelse av en bestemt gruppes kultur (Anderson, 2002). Den valgte strategien kan heller beskrives som institusjonell etnografi (Smith, 2005) som ikke forventes å gi representativ kunnskap, men framstod som velegnet til å øke vår kunnskap om og forståelse av arbeidsinnkludering i praksis.

Institusjonell etnografi er basert på en idé om at sosiale prosesser bør studeres og forstås i den sosiale og kulturelle konteksten de inngår i. Gjennom å bruke tid i et sosialt fellesskap får forskeren mulighet til å beskrive hverdagslivets aktiviteter, og de perspektivene som vokser ut fra det, med et blikk innenfra. For å forstå og tolke dette hverdagslivet, er alle typer kilder, materialer og metoder aktuelle. Det er med andre ord en god metode for å beskrive og forklare en virksomhet og som innbyr til en kombinasjon av alle typer metoder, materialer og analyser (Widerberg, 2007).

Vi søkte etter kunnskap om samspillet mellom de medvirkende og deres selvoppfatning og sosiale identiteter i en gitt kontekst av ulike aktiviteter med mål om arbeidsinnkludering i praksis. Identitet formes av hvordan man ses på av andre som et sosialt objekt og hvordan man selv viser det. Men identiteten er ikke statisk, men endres i takt med at den enkeltes situasjon endres eller omdefineres i samspillet med omgivelsene (Mead, 2015; Stone, 1962; Stryker, 1980; Trost \& Levin, 2010).

Den empiriske studien var basert på en kvalitativ tilnærming. Hensikten med en kvalitativ studie, er å bruke de innsamlede dataene til å oppnå en dypere forståelse for et bestemt tema og deretter trekker konklusjoner (Svenning, 2000).

Kvalitative studier påvirkes på ulike måter av forskerens forforståelse om det som skal studeres. For å forklare og forstå menneskers handlinger kan vi ta i bruk en forklaringsmodell.

I vår studie så vi etter en forklaringsmodell, med utgangspunkt i hvordan aktørene selv beskriver sin situasjon og sine handlinger i en pågående arbeidsinkluderingsprosess. Symbolsk interaksjonisme er et teoretisk begrep eller perspektiv, beskrevet av sosiologen Herbert Blumer (1937) og et utgangspunkt for å forstå et sosialt samspill og konstrueringen av identitet mellom mennesker (Blumer, 1937; Trost \& Levin, 2010).

I følge Mandal et al. (2019) er arbeidsinnkludering et komplekst fenomen, der flere aktører kan være involvert og der målsetting og fremdriftsplan vil variere. Teoretiske perspektiver, som den symbolske interaktionismen, inneholder grunnleggende forestillinger om den sosiale virkeligheten og hjelper oss å forstå. 
Målet er ikke å beskrive og forklare årsak og virkning i ulike situasjoner, men forståelse av det vi møter (Merton \& Merton, 1968; Trost \& Levin, 2010).

\section{Den praktiske gjennomføringen av studien}

I vår studie deltok tre arbeidssøkende i ulik alder (i aldersspennet ca. 30-45 år), begge kjønn, med lik identitet som deltaker i en arbeidsinkluderingsprosess. Dessuten medvirket to jobbkonsulenter og to mellomledere fra bedriften og to veiledere fra NAV. Forskningsgruppen bestod av tre forskere som gjennomførte tre besøk i lokalene til arbeidsinnkluderingsbedriften.

Valget av informanter ble gjort i samråd med bedriften og kan beskrives som et samspillende utvalg. Et slikt utvalg karakteriseres av at informantene har en form for relasjon til hverandre tre (Tresselt et al., 2018). De medvirkende ble informert om hensikten med studien og hvilke metoder som skulle anvendes, samt at arbeidet skulle gjennomføres etter gjeldende etiske retningslinjer. Vi informerte om at deltagelsen i studiet var frivillig og at man med umiddelbar virkning kunne trekke sitt samtykke.

Ut i fra en felles etisk holdning har vi valgt å ikke nærmere beskrive og presentere de deltagende aktørene. $\AA$ ivareta alle aktørenes personlige integritet var en forutsetning for den praktiske gjennomføringen.

Datainnsamlingen ble innledet med et fokusgruppeintervju med jobbkonsulenter fra bedriften og veiledere fra NAV, der vi fokuserte på samspillet mellom bedriften som organisasjon og NAV som institusjon. Forskerne gjennomførte deretter tre semistrukturerte dybdeintervjuer med tre arbeidssøkere hver. Det samlede intervjumaterialet består dermed av ni intervjuer. Med disse intervjuene ville vi få innsikt i hvordan informantene opplevde sin situasjon som arbeidssøkere og hva de tenkte om egen læring og veien ut i arbeidslivet (Peräkylä \& Ruusuvuori, 2013). I tillegg gjennomførte vi hver gang 2-4 spontane dybdeintervjuer for å innhente informasjon fra jobbkonsulentene og NAV veiledere. Spontane dybdeintervju (Henriksen \& Tøndel, 2017) er en metode som består av intervjudata fra korte, avgrensede og spontane intervjuer, og aktiv bruk av observasjon. Metoden går direkte i dybden på et fenomen og gir forskeren mulighet til å avgrense forskningen (Tjora \& Tjora, 2021).

\section{Etnografisk analyse}

Etnografiske studier innebærer at forskeren gjennom feltarbeid observerer og beskriver mennesker, praksiser og kulturer i deres naturlige miljø for å få innsikt det som skal studeres. Forskerens tilstedeværelse i hverdagen bidrar til å oppfylle kravene til validitet (Larsson, 2005). Den etnografiske analysen defineres av Coffey (1999) som framvoksende gjennom en gradvis økning av data og en induktiv analyse av det innsamlede materialet. Forskerens intuisjon og kreativitet 
påvirker den analytiske forståelsen (Lofland, 1995). Beskrivelsene av resultatene fra innsamlede data gjøres med hensikt å relatere spesielle handlinger eller hendelser til den aktuelle sammenhengen (Denscombe, 2017). Noen observasjoner under korte besøk i et tidligere ukjent miljø er ikke tilstrekkelig til å identifisere innholdet og strukturen i prosessen med arbeidsinnkludering. For å unngå metodiske problemer begrenset vi oss til arbeidssøkernes, NAV veiledernes og jobbkonsulentenes egne beskrivelser, med vekt på sistnevnte. Det hadde vært ønskelig å ha mer detaljert og nyansert informasjon fra arbeidssøkere, men dette ble $\mathrm{i}$ stor grad hindret av deres språkproblemer.

Resultater fra etnografiske intervjuer bør vises som realistiske fortellinger (Van Maanen, 2011). Med utgangspunkt i van Maanen (2011) har vi derfor valgt å vise resultatene fra intervjuene med informantene i studien som hele uttalelser og deler av en dialog, snarere enn som redigerte og isolerte sitat (Davies, 2012; Toikkanen, 2016).

\section{Arbeidsinnkludering i et aktørperspektiv}

I fravær av entydige og empirisk identifiserbare grenser, kan inkludering i arbeid som fenomen kun oppleves og beskrives subjektivt. Dette er basert på den kulturelle og profesjonelle bakgrunnen til aktørene. Kulturer endres og påvirkes av det sosiale miljøet, men også gjennom utviklingsfasene i prosessen. I vår studie så vi på hvilke faktorer som kan medvirke til å gjøre det utfordrende å finne jobb til en arbeidssøker. Vi spør om dette handler om faktorer i eller rundt deltakeren, det kan være helseutfordringer, forhold i familien, boforhold osv.

Jeg opplever at jeg blir akseptert, men vet ikke hvordan det skal gå fremover. Jeg
skal se fremover hvordan jeg fungerer, hvordan jeg føler meg, etter at jeg har job-
bet i to uker eller tre uker, da vurderer jeg meg selv, hvordan jeg føler meg. Og de
på sykehjemmet skal si hva de synes om meg. De skal gi meg tilbakemelding.
(Arbeidssøker 1)

Ja, jeg har mine venner, men det er Eritrea. (Arbeidssøker 2)

Videre kan det tenkes at det er forhold ved arbeidsplassen eller i samfunnet som f.eks. lovverket og endringer i arbeidslivet som vanskeliggjør deltakelse i arbeidslivet i tillegg til det informantene sier om inkludering og sosial tilpasning til nye forhold både privat og yrkesmessig.

[...] og det er greit, men da må vi begrunne hvorfor på en faglig måte og ikke, ikke mer sånn: Nei, her er det så vanskelig. (Jobbkonsulent)

NAVs rolle i inkluderingsprosessen framheves som viktig for å lykkes. NAV veilederne beskriver en sømløs prosess der deltaker skal føle seg trygg på at systemene kommuniserer og legger til rette for at overganger ut $\mathrm{i}$ arbeid er preget av 
Arbeidsinnkludering som en vei til varig arbeidslivstilknytning og et verdig voksenliv

kontinuitet og trygghet for den enkelte deltaker. Dette er en samhandling mellom aktørene som skal bistå og trygge deltaker i prosessen.

[...] og da er det liksom overgangen fra NAV systemet til arbeidslivet, men det er jo der egentlig at den fagligheten i inkluderingsprosessen, den bør jo være sømløs da, og gå på tvers av alle. Sånn at det ikke blir sånne hakk imellom at nå er du ferdig med NAV også har du jobb, og så må du egentlig dette ut av jobb før du kan få hjelp igjen, så det er ... det er viktig. (NAV veileder)

Tett kontakt mellom arbeidssøker og jobbkonsulent i arbeidet med å finne egnet arbeidsplass anses også som avgjørende. Deltakers ressurser, ønsker og muligheter blir kartlagt under samtaler i oppstarten av programmet, og dette ses videre i forhold til muligheter og krav i arbeidsmarkedet.

Det å holde fast på målet, trygghet i metoden, jobbe systematisk og målretta hele tida og dermed være profesjonell i rollen. Det tror jeg er, det er et suksesskriterie som ikke kommer fram. (Jobbkonsulent)

Når man jobber lærer man fort. Man ser hvordan de gjør det. Lærer mer i praksis enn på teorien. Og språk. Spesielt eldre. Da prater du med dem. De prater mye. De snakker bra norsk. Det er også sosialt. (Arbeidssøker 1)

Det er bedriften som sier hvilken kompetanse og egenskaper deres ansatte må ha, og det danner grunnlaget for arbeidstreningen videre. Samtidig vektlegges det at man i arbeidet med å finne egnet arbeid og bistå med arbeidsinnkludering, har et realistisk syn på den enkelte arbeidssøkers begrensinger og utfordringer. Det er viktig at de arbeidssøkende og jobbkonsulentene har et felles og praktisk forankret syn på innholdet i arbeidet som utføres i hverdagen.

Jeg snakket med de eldre når de spiste frokost. Jeg hadde det bra, men jeg mangler mye erfaring. Jeg må bli kjent med hvilke behov de eldre har. (Arbeidssøker 1)

Da kan vi tenke at det er en ekkel fyr som ikke klarer å vaske seg. Men han skal jobbe på verksted lang inne i skogen her, da hadde det vært veldig rart om han var fryktelig rein. Ikke sant? (Jobbkonsulent)

Jobbkonsulentene sier at en god struktur med faste rutiner er viktig for at prosessen med arbeidsinnkludering skal kunne fullføres. I den innledende fasen kartlegges deltakernes kompetanse og hvilke muligheter dette gir på arbeidsmarkedet. Samtidig vektlegges den enkelte arbeidssøkerens eget ansvar

Vi må bare gi dem den oppfølginga, og hvis vi lurer på om vi syr puter opp under armene på dem, så se deg selv i speilet og spør om du har kartlagt godt nok. (Jobbkonsulent)

Samtidig beskrives den arbeidssøkendes eget ansvar, slik det framgår av sitatet under.

Tror jeg kan få jobb om jeg klarer meg selv. Klarer å jobbe noe selvstendig i dag, kjøkken, servere mat og re opp seng. (Arbeidssøker 1) 
Arbeidsinnkludering forutsetter et fleksibelt samarbeide mellom flere parter over tid, der målet er å finne alternativer for hver enkelt arbeidssøkende ut ifra kompetansen som er kommet fram under kartleggingen. Den innledende kartleggingen beskrives som en "mulighetsstudie" og jobbkonsulentens oppdrag er å, ut ifra det som kommer fram der, bidra til å motivere den arbeidssøkende $\mathrm{i}$ forhold til de mulighetene som blir presentert.

Og hvis du klarer å få ... deltageren til å si at: Jo jeg har masse muligheter jeg. Da har du plutselig masse muligheter til å komme deg ut i aktivitet på, og ikke fokusere på, som ble sagt før i dag, det som er at dem begynner med den: Hva er hindringene dine? (Jobbkonsulent)

Det er viktig at arbeidssøkerne er realistiske i møte med kravene på hva slags kunnskap og ferdighet som trengs for å imøtekomme de forventningene som stilles.

Lære mer faglig. Og kunne jobbe selvstendig. Og ha mulighet til å dekke arbeidsoppgavene, så jeg trives på jobb. Jeg må se hva de gjør og ikke gjøre noe annerledes. (Arbeidssøker 1)

Motivasjon er et nøkkelord i arbeidsinnkludering. Å motivere hver enkelt deltaker til å bygge opp sin selvfølelse og tro på det å få til noe, "Til å finne den lille oppgaven som gjør at dem får troa på at: Jo, det er noe i meg som gjør at jeg kan ha en verdi $i$ arbeidsmarkedet" (Jobbkonsulent). Men forventningene til å lykkes må som nevnt over, være realistiske.

Men, det er den koblinga at alt motivasjonsarbeid, egentlig alt som vi prater med deltakerne om handler om å finne den koblinga der dem som er bevis på at dem kan gjøre en oppgave. Da, det er jo da du føler deg sett og hørt og tatt på alvor og. For det hjelper ikke at vi som mennesker sitter og sier at: Du er fin nok som du er. (Jobbkonsulent)

I samtalene våre med de arbeidssøkende kom det fram at de hadde tro på å kunne lykkes i arbeidslivet i tillegg til å kunne utvikle seg vidare over tid.

Og jeg er veldig motivert. Jeg vil ut å jobbe for å utvikle meg og få fagbrev. Og vil utvikle meg med utdanning. Hvis jeg klarer fagbrev, er det ikke vanskelig å utvikle meg videre. Har lyst til å bli sykepleier, men må se senere. (Arbeidssøker 1)

\section{Fra arbeidsinnkludering til skole}

Muligheten for å overføre metoder fra arbeidsinnkludering til skolen ser jobbkonsulentene som problematisk. Ifølge dem begrenser den pedagogiske virksomheten forståelsen for verdien av elevens kunnskap og evner.

Det er snakk om kartlegging for et verdig voksenliv, og ikke et verdig skoleliv. Og den store forskjellen. Så for de som virkelig sliter, så er det ikke noe vits $i$ å få beskjed om at du er dårlig på en måte, for det vet dem jo. Og hvor ille det er. Men da er det mere viktig å se på den koblinga, hva kan du gjøre. Og hvor kan du gjøre det. (Jobbkonsulent) 
En arbeidssøkende hevder imidlertid at det er mulig å overvinne de organisatoriske hindringene for å implementere metoder for arbeidsinnkludering i samhandling med skolen. Det handler om å finne en felles holdning til og syn på hva som er praktisk kunnskap og hva den kan brukes til.

\section{[...] det er en tanke at problemløsning er hensikten med hva en kan anse som prak- tisk kunnskap. Hvis denne tanken stå til prøve, så er det mulig at en oppgave som må løses, kan gi en praktisk kontekst til en teori, og dermed giøre kunnskapen praktisk i sinnet til personen som bruker den. (Arbeidssøker 3)}

Jobbkonsulentene er ikke overbevist om at skolen har tilstrekkelige muligheter for å møte hver enkelt elevs behov for å lære og utvikles i forberedelsen til et verdig voksenliv og deltakelse i arbeidslivet.

Det kan ikke skje som forberedelse. Det sier jo på en måte all erfaring og teori. i arbeidslivet, om arbeidsinnkludering. Så hvorfor tenker vi at det er greit i skolen. Det kan ikke skje i skolen, og hvert fall ikke for de som strever mest. (Jobbkonsulent)

Arbeidssøkere og jobbkonsulenter synes allikevel å være enige om at praktisk kunnskap er en suksessfaktor for arbeidsinnkludering og et område der skole og arbeidsliv kan nærme seg og lære av hverandre.

Da jeg personlig har møtt personer, og selv til tider tenkt at informasjon var "nytteløs" fordi jeg eller de ikke så nytten i den spesifikke kunnskapen.

(Arbeidssøker 3)

Det er sånn vi tenker, altså bygger opp egenskaper når du skal prate om sine.. egenskap: Hvordan fungerer det, og hva er fordelen for arbeidsgiveren at du er akkurat på den måten der. Så konkret er vi. Og da ... når vi jobber med den metodikken hos deltakerne, da tar de poenget. (Jobbkonsulent)

I det empiriske materialet ser vi at bedriftens metode utfordrer deltakerne på hva de har kompetanse i og interesse for med utgangspunkt i hvordan dette kan settes i spill og videreutvikles i arbeidslivet (Lassen, 2008; Seligman, 2012). Vi ser hvordan relasjoner og god kommunikasjon mellom deltakerne og jobbkonsulentene medvirker til å fremme vekst og finne gode løsninger for den enkelte. Dette kan ses på og oppleves som bestyrkende som kan påvirke deltakernes muligheter i arbeidslivet (Breilid \& Dyrnes, 2017; Dyrnes, 2013; Lassen \& Breilid, 2010; Sletten \& Hyggen, 2013).

- Tett individuell oppfølging

- Individuell tilpasning og tilrettelegging med mulighet for medvirkning og å ta styring i eget liv

- Tverrgående samarbeid og helhetlig tilnærming

- Tidlig intervensjon og forebygging på flere arenaer

- Ubyråkratiske strukturer som inviterer til kontakt og rask innsats 


\section{Drøfting}

I arbeidet med å tilrettelegge og forberede for arbeidslivsdeltakelse, mener vi at blant annet faktorene over kan være avgjørende og påvirke den enkeltes muligheter for arbeidslivsdeltakelse. Dette ser vi som avgjørende, i tillegg til å identifisere muligheter for samhandling mellom skole og arbeidsliv. Tilpasset videregående opplæring og et opplæringsløp der elevene planlegger å være lærekandidat framfor lærling med de muligheter og tilpasninger det innebærer, er her et alternativ.

Ifølge vår forklaringsmodell er det viktig for den enkelte å definere den situasjonen man befinner seg $i$, ut i fra sine egne oppfatninger og erfaringer. Det bildet av situasjonen som konstrueres blir dermed styrende for den enkeltes identitetsoppfatning. Når situasjonen omdefineres kan også identiteten og dermed motivasjonen for å fullføre endres (Trost \& Levin, 2010). En elevs endrede identitet fra å gå mot lærlingkontrakt og fagbrev til lærekandidat og kompetansebevis, er et eksempel på en slik omdefinering.

Vi ser at manglende tilgang på egnede arbeidsplasser som opplæringsarenaer for ungdom, som en følge av et arbeidsliv i endring, også skaper utfordringer og spenninger i arbeidet med å bistå ungdom på veien ut i varig arbeidslivstilknytning.

Videre kan det se ut som at skole og arbeidsliv som systemer ikke har samme kompetanse som f.eks. om hvilke kompetansekrav som stilles i arbeidslivet. Dette handler videre om hvordan ungdom forberedes på å møte arbeidslivets krav og forventninger. I norske læreplaner for yrkesfaglige program i Fagfornyelsen ${ }^{4}$, ser vi at det i større grad enn tidligere er lagt vekt på at undervisningen skal fremme og vektlegge opplæringen som framtidsrettet og relevant både for elever og lærlinger/lærekandidater, samt reflektere bedrifters og virksomheters behov for kompetanse (NOU 2019:12). Det betyr bl.a. at det skal legges vekt på en tverrfaglig og helhetlig opplæring med vekt på både elevenes yrkesinteresser og motivasjonen for å øke mulighetene for å fullføre utdanningen og bli deltakere i arbeidslivet. Dette vil i tillegg, slik vi ser det, styrke kvaliteten på yrkesopplæringen.

Ifølge Utdanningsdirektoratet kan mulighetene for å fullføre videregående opplæring bedres ved at elever som har utfordringer med å nå målet om full måloppnåelse, benytter seg av lærekandidatordningen og får en opplæringskontrakt med en bedrift eller virksomhet.

Å fullføre videregående opplæring anses som svært viktig for den enkeltes tilgang til og deltagelse i arbeidslivet. Dette har også stor betydning med tanke på muligheter for medborgerskap og aktiv samfunnsdeltagelse med mål om et verdig voksenliv. Ekspertutvalget for etter- og videreutdanning viser også til videregående skole som en ressurs for næringslivet med tanke på intensjonen om 
livslang læring, kompetanseheving og kvalifisering for arbeidslivet (NOU 2019:12).

For å motvirke utenforskap og fremme inkludering og deltakelse i arbeidslivet, ser vi i vår studie at bedriften $\mathrm{i}$ sitt arbeid og med sin kompetanse på arbeidsmarkedets behov, er opptatt av å ta i bruk et bestyrkende perspektiv bl.a. ved å synliggjøre deltakernes evner, ressurser og interesser. I en studie av læring og arbeidsvaner hos lærlinger (Garmannslund \& Witsø, 2017) sier lærlinger at det har betydning for deres læring, måloppnåelse og trygghet at de har jevnlige samtaler med veileder om hvordan det går med dem på arbeidsplassen. Dette samsvarer med våre funn. I tillegg framhevet både jobbkonsulentene og de arbeidssøkende betydningen av å være ressursorientert og ikke for opptatt av utfordringer og begrensinger hos den enkelte arbeidss $ø$ kende i samhandlingen om prosessen $\mathrm{i}$ å finne egnet arbeid.

Det vektlegges i tillegg å legge til rette for å støtte og ta i bruk de arbeidssøkendes kompetanse, interesser og motivasjon. Samarbeid og motivering ble også løftet fram som betydningsfulle faktorer i arbeidet med arbeidsinnkludering. Dette er kjente faktorer fra yrkesopplæringen i skole, og som også ble framhevet i Breilid og Dyrnes (2015) sin studie.

Dette kommer i tillegg til å ta i bruk lovverket på en inkluderende måte for å fremme den enkeltes muligheter for å lykkes i overgangen til arbeidslivet.

Rorty og Richard (1989) hevder at den enkeltes definisjon av den sosiale virkeligheten bare er en av flere mulige beskrivelser, som kan omdefineres når samspillet mellom individet og omgivelsene endres (Rorty \& Richard, 1989). Vi så i vår studie at et fungerende sosioøkologisk nettverk og samspillet med dette er av betydning, og at bedriften i sitt arbeid er bevisst på det og legger til rette for å styrke og fremme det $\mathrm{i}$ arbeidet med å bistå arbeidssøkere $\mathrm{i}$ å bli inkludert $\mathrm{i}$ arbeidslivet og dermed forebygge utenforskap.

Faktorer som beskrevet over ser ut til å fremme arbeidslivstilknytning i et arbeidsliv i stadig endring både nasjonalt og i europeisk sammenheng. Dette kan se ut til å være av betydning for arbeidssøkende som av ulike grunner har falt ut av arbeidslivet. I tillegg er det interessant å se til konkrete metoder som benyttes $\mathrm{i}$ arbeidsinnkluderingsbedriften $\mathrm{i}$ arbeidet med å legge til rette for at lærekandidater oppnår varig tilknytning til arbeidslivet på veien mot et verdig voksenliv.

\section{Veien videre}

Med utgangspunkt i det vi forstår med livslang læring ser vi det slik at læring ikke kun og hovedsakelig skal foregå i skolen, men også videre i livet etter fullført utdanning. Bedrifter og virksomheter blir dermed en viktig arena både for læring og varig arbeidslivstilknytning. Det vil si at aktører utenfor skolen også må ha kunnskap om læring og betingelser for læring. Vi har sett på rollene til jobbkonsulentene ved arbeidsinnkluderingsbedriften og NAV veilederne. Med 
utgangspunkt i dette, stiller vi spørsmål ved om deres utøvelse og forståelse av rollen sin overfor de arbeidssøkende, kan overføres til lærerrollen ved yrkesfaglige utdanningsprogram i videregående skole. I materialet vårt ser vi imidlertid at både en jobbkonsulent og en arbeidssøkende mener at metoder fra arbeidet med arbeidsinnkludering ikke nødvendigvis kan overføres direkte til skolen på grunn av organisatoriske hindringer, men at tilpasninger må til. Det framkommer at skole og arbeidsliv har mye å lære av hverandre i arbeidet med arbeidsinnkludering. Vi vet imidlertid ikke nok om videregående skole som organisasjon og dens rolleutøvelse på dette området til å si noe om hvordan og under hvilke rammer det der kan utvikles nye måter å tenke og handle på. Dette er et interessant område å forske videre på.

Vi ønsker derfor videre å forske på hvordan videregående skole forbereder yrkesfagelever som har ulike utfordringer i skolehverdagen, og som velger lærekandidatordningen, for varig arbeidslivstilknytning og et verdig voksenliv. Spørsmål som det er interessant å se nærmere på:

- Hvordan forberedes eleven på møtet med arbeidslivet?

- Hvilke endringer i arbeidslivet forberedes elevene på og hvordan?

- Er skolen og arbeidslivet tilpasset til hverandre i forhold til den enkeltes evner og muligheter til arbeidslivsdeltakelse?

Videre vil det være interessant å se på muligheter for utprøving og implementering av metoder fra arbeidsinnkludering i yrkesopplæringen for å øke muligheten for varig arbeidslivsdeltakelse og et verdig voksenliv for yrkesfagelevene.

\section{Sluttnoter}

${ }^{1}$ Lærekandidatordningen er tilpasset de elevene som ønsker videregående opplæring i bedrift, men som ikke har forutsetninger for å nå kravene til fag- og svenneprøven. Dette kalles dokumentert delkompetanse, og betyr at enten utvalgte fag eller mål fra læreplanen kan tas ut slik at elevene kan konsentrere om færre mål og fag enn de elevene som går opp til fagprøve/eksamen. Det kan søkes om opplæringskontrakt i en bedrift eller virksomhet $\mathrm{i}$ det aktuelle yrkesfaglige utdanningsprogrammet. Etter endt læretid går lærekandidaten opp til en kompetanseprøve og får etter det tildelt et kompetansebevis det reell oppnådd kompetanse i yrket er beskrevet.

${ }^{2}$ En lærling utdanner seg til et yrke ved å arbeide to år i en bedrift eller virksomhet etter å ha fullført to år på et yrkesfaglig program i videregående skole. Etter fullført læretid gjennomføres en fagprøve for å få fagbrev.

${ }_{3}^{3}$ Tidligere Akershus fylke er siden 2020 en del av Viken fylke.

${ }^{4}$ Det ble i skoleåret 2020/21 innført nye læreplaner i fag-i grunnopplæringen samt ny overordnet del av læreplanverket i Norge. Dette har fått navnet Fagfornyelsen. 
Arbeidsinnkludering som en vei til varig arbeidslivstilknytning og et verdig voksenliv

\section{Om forfatterne}

Eva Martinsen Dyrnes er førstelektor i yrkespedagogikk ved Høgskolen i Østfold. Hun underviser på PPU for yrkesfag og i videreutdanning for yrkesfaglærere. Hennes forskningsinteresser er yrkesfagelever i lærekandidatordningen og deres muligheter for arbeidslivstilhørighet. I tillegg forsker hun på hvordan PPU studiet behandler og forbereder studentene på møtet med mangfoldet i skolen.

Dan Roger Sträng er professor i pedagogikk ved Høgskolen i Østfold. Sträng har arbeidet med vekt på skole- og næringsutvikling i offentlig sektor. Som prosjektleder og veileder for utviklingsprosesser har han i flere år studert og evaluert organisasjonenes evne til å identifisere og beskrive aktuelle områder for utvikling og fornyelse. 


\section{Referanser}

Alvehus, J. (2013). Skriva uppsats med kvalitativ metod: En handbok. Liber.

Anderson, L. (2002). Interpersonell kommunikation: En studie av elever med hörselnedsättning $i$ särskolan. [Doktorgradsavhandling, Malmö högskola, Forskarutbildningen i pedagogik]. https://lup.lub.se/record/20874

Askheim, O. P. (2003). Fra normalisering til empowerment: Ideologier og praksis $i$ arbeid med funksjonshemmede. Gyldendal akademisk.

Bakken, A. \& Elstad, J. (2012). For store forventninger? Kunnskapsløftet og ulikheter i grunnskolekarakterer (NOVA Rapport 7/2012). Norsk institutt for forskning om oppvekst, velferd og aldring.

Berger, T. \& Frey, C. B. (2016). Structural transformation in the OECD: Digitalisation, deindustrialisation and the future of work (OECD Social, Employment and Migration Working Papers, No. 193). OECD Publishing. https://doi.org/10.1787/5jlr068802f7-en

Blumer, H. (1937). Social psychology. I E. P. Schmidt (Red.), Man and society: A substantive introduction to the social science (s. 144-198). Prentice Hall.

Bonoli, G. (2010). The political economy of active labor-market policy. Politics $\mathcal{E}$ Society, 38(4), 435-457. https:/ / doi.org/10.1177/0032329210381235

Breilid, N. \& Dyrnes, E. M. (2017). Bestyrkende faktorer som fremmer en positiv overgang fra skole til varig arbeidslivstilknytning for elever i lærekandidat-ordningen. Scandinavian Journal of Vocation in Development, 2, 1-22. https:/ / doi.org/10.7577/ sjvd.2179

Coffey, A. (1999). The ethnographic self: Fieldwork and the representation of identity. Sage.

Davies, C. A. (2012). Reflexive ethnography: A guide to researching selves and others. Routledge.

Denscombe, M. (2017). The good research guide: For small-scale social research projects. McGraw-Hill Education.

Dyrnes, E. M. (2013). Det gode møtet som motivasjon til å fullføre. Bedre skole, (1), 65-68.

Eide, H. M. K., Homme, A., Karlsen, M.-A. \& Lundberg, K. (2017). Omsorgssektoren som integreringsarena. Tidsskrift for velferdsforskning, 20(4), 332348. https:/ / doi.org/10.18261/issn.2464-3076-2017-04-06

Emblemsvåg, M. S. (2020). Frafall i skolen: En utfordring for hele Norden. Utdanningsnytt.

Falch, T. \& Nyhus, O. H. (2009). Frafall fra videregående opplæring og arbeidsmarkedstilknytning for unge voksne (SØF-rapport nr. 07/09). Senter for økonomisk forskning.

Frøseth, M. W., Hovdhaugen, E., Høst, H. \& Vibe, N. (2010). Fra andre til tredje år i videregående opplaring. NIFU.

https://www.udir.no/tall-og-forskning/finn-forskning/rapporter/Fraandre-til-tredje-ar-i-videregaende-opplaring---tredje-delrapport-2010/ 
Arbeidsinnkludering som en vei til varig arbeidslivstilknytning og et verdig voksenliv

Garmannslund, P. E. \& Witsø, H. (2017). Lærings- og arbeidsvaner hos lærlinger. Nordic Journal of Vocational Education and Training, 7(1), 23-41. https://doi.org/10.3384/njvet.2242-458X.177123

Henriksen, I. M. \& Tøndel, G. (2017). Spontane dybdeintervjuer: Strategisk interaksjon som sosiologisk forskningsmetode. Norsk sosiologisk tidsskrift, 1(3), 216-232. https://doi.org/10.18261/issn.2535-2512-2017-03-02

Hilden, P. K. \& Middelthon, A.-L. (2002). Kvalitative metoder i medisinsk forskning: Et etnografisk perspektiv. Tidsskrift for Den norske legeforening.

Kompetanse Norge. (u.å.). Ekspertutvalg for etter- og videreutdanning (2018-2019). Kompetanse Norge. https://www.kompetansenorge.no/evu/

Larsson, S. (2005). Om kvalitet i kvalitativa studier. Nordic Studies in Education, 25(1), 16-35.

Lassen, L. M. (2008). Hvordan prinsippene i empowerment kan anvendes som metode ved spesialpedagogisk rådgivningsarbeid. I E. Befring \& R. Tangen (Red.), Spesialpedagogikk (4. utg., s. 154-169). Cappelen akademisk forlag.

Lassen, L. M. (2014). Rådgivning: Kunsten å hjelpe og sikre vekstfremmende prosesser (2. utg). Universitetsforlaget.

Lassen, L. M. \& Breilid, N. (2010). Den gode elevsamtalen. Gyldendal akademisk.

Lassen, L. M. \& Breilid, N. (2012). Foreldresamarbeid i praksis: Et verktøy for foreldre, lærere og elever for å skape utviklingsfremmende prosesser. Fagbokforlaget.

Lofland, J. (1995). Analytic ethnography: Features, failings, and futures. Journal of Contemporary Ethnography, 24(1), 30-67. https://doi.org/10.1177/089124195024001002

Mandal, R., Midtgård, T. M. \& Mordal, S. (2019). Arbeidsinkludering: Med arbeidsgiverne på laget. SINTEF.

Markussen, E. (2014). Utdanning lønner seg: Om kompetanse fra videregående og overgang til utdanning og arbeid ni år etter avsluttet grunnskole 2002 (NIFURapport 1/2014). Nordisk institutt for studier av innovasjon, forskning og utdanning.

Markussen, E., Grøgaard, J. B. \& Hjetland, H. N. (2018). «Jeg vet ikke hva alternativet skulle vært»: Evaluering av lærekandidatordningen og av ordningen med tilskudd til opplæring av lærlinger, praksisbrevkandidater og lærekandidater med særskilte behov (NIFU-Rapport 2018:8). Nordisk institutt for studier av innovasjon, forskning og utdanning. http:/ / hdl.handle.net/11250/2500663

Mead, G. H. (2015). Mind, self, and society: The definitive edition. University of Chicago Press.

Meld. St. nr. 20 (2012-2013). (2013). På rett vei: Kvalitet og mangfold i fellesskolen. Kunnskapsdepartementet.

https://www.regjeringen.no/contentassets/53bb6e5685704455b06fdd28 9212d108/no/pdfs/stm201220130020000dddpdfs.pdf 
Menon, S. (2001). Employee empowerment: An integrative psychological approach. Applied Psychology, 50(1), 153-180. https:// doi.org/10.1111/1464-0597.00052

Merton, R. K. \& Merton, R. C. (1968). Social theory and social structure. Simon and Schuster.

NOU 2001:22. Fra bruker til borger: En strategi for nedbygging av funksjonshemmende barrierer. Statens forvaltningstjeneste, Informasjonsforvaltning. https://www.regjeringen.no/contentassets/1e18b045dd9346849813392b 34c9cdc1/no/pdfa/nou200120010022000dddpdfa.pdf

NOU 2012:6. Arbeidsrettede tiltak. Arbeids- og sosiadepartementet. https://www.regjeringen.no/no/dokumenter/nou-2012-6/id672029/

NOU 2018:2. Framtidig kompetansebehov 1. Kunnskapsdepartementet. https://www.regjeringen.no/no/dokumenter/nou-2018-2/id2588070/

NOU 2019:12. Lærekraftig utvikling: Livslang læring for omstilling og konkurranseevne. Kunnskapsdepartementet. https://www.regjeringen.no/no/dokumenter/nou-2019-12/id2653116/

Olsen, T., Hyggen, C., Tägtström, J. \& Kolouh-Söderlund, L. (2016). Unge i risiko: Overblik over situationen i Norden. I Unge, udenforskap og social forandring: Nordiske perspektiver (s. 39-68). Frydenlund Academic.

Opplæringslova. (1998). Lov om grunnskolen og den vidaregåande opplæringa. https:/ /lovdata.no/dokument/NL/lov/1998-07-17-61

Pajarinen, M., Rouvinen, P. \& Ekeland, A. (2015). Computerization threatens onethird of Finnish and Norwegian employment. Etla Brief, 34, 1-8.

Patzina, A. \& Wydra-Somaggio, G. (2020). Early careers of dropouts from vocational training: Signals, human capital formation, and training firms. European Sociological Review, 36(5), 741-759. https://doi.org/10.1093/esr/jcaa011

Peräkylä, A. \& Ruusuvuori, J. (2013). Analyzing talk and text. I N. K. Denzin \& Y. S. Lincoln (Red.), Collecting and interpreting qualitative materials (4. utg., Bd. 4, s. 277-307). SAGE Publications.

Ronnby, A. (1983). Psykologiska förklaringsmodeller i socialt arbete (Research Reports in Social Work 5). Socialhögskolan, Lunds universitet.

Rorty, R. \& Richard, R. (1989). Contingency, irony, and solidarity. Cambridge University Press.

Schwab, K. (2018). The global competitiveness report 2018. World Economic Forum.

Schøyen, M. A. (2016). Den norske velferdsstaten: En sosial investeringsstat? Tidsskrift for velferdsforskning, 19(1), 4-23.

Seligman, M. E. (2012). Flourish: A visionary new understanding of happiness and well-being. Simon and Schuster.

Sletten, M. A. \& Hyggen, C. (2013). Ungdom, frafall og marginalisering: Temanotat. Norges forskningsråd.

Smith, D. E. (2005). Institutional ethnography: A sociology for people. Rowman Altamira. 
Statens arbeidsmiljøinstitutt. (2016). Årsrapport 2016. Statens arbeidsmiljøinstitutt.

StatistiskSentralbyrå. (2019, 28. juni). Sysselsetting blant unge mottakere av helserelaterte ytelser.

https://www.ssb.no/sosiale-forhold-og-kriminalitet/artikler-ogpublikasjoner/flere-unge-ufore-faerre-arbeider-samtidig

Stone, G. P. (1962). Appearance and the self. I A. M. Rose (Red.), Human behavior and social processes: An interactionist approach (s. 86-118). Houghton Mifflin.

Strand, A. H. \& Nielsen, R. A. (2015). Veier inn i, gjennom og ut av arbeidsavklaringspenger: Hvor langt unna arbeidslivet står mottakerne? (Faforapport 2015:29). Fafo.

Stryker, S. (1980). Symbolic interactionism: A social structural version. BenjaminCummings Publishing Company.

Svenning, C. (2000). Metodboken: Samhällsvetenskaplig metod och metodutveckling Klassiska och nya metoder i IT-samhället. Lorentz.

Tjora, A. H. \& Tjora, A. H. (2021). Kvalitative forskningsmetoder i praksis (4. utg.). Gyldendal.

Toikkanen, J. J. (2016). Home Office (Hoffice): En etnografisk studie om ett coworkingfenomen. Svenska handelshögskolan.

Tresselt, M. A., Andreassen, S.-E. \& Lund, T. (2018). Teammøter i skolen: Fra «logistikkmøter» til lærende møter? Forskning E Forandring, 1(1), 78-100. https:/ / doi.org/10.23865/fof.v1.1003

Trost, J. \& Levin, I. (2010). Att förstå vardagen: Med ett symbolisk interaktionistiskt perspektiv. Studentlitteratur.

Tøssebro, J. \& Wik, S. E. (2013). Unge funksjonshemmede i møte med NA V: Ett år med arbeidsavklaring. NTNU Samfunnsforskning. http:/ / hdl.handle.net/11250/2365875

Utdanningsdirektoratet. (2018). Overordnet del av læreplanverket. Utdanningsdirektoratet. https:/ / www.udir.no/lk20/overordnet-del/?lang=nob

Utdanningsdirektoratet. (2021a). Føring av vitnemål og kompetansebevis for videregående opplæring $i$ Kunnskapsløftet - 2021. Utdanningsdirektoratet. https://www.udir.no/eksamen-og-prover/dokumentasjon/vitnemalog-kompetansebevis/foring-vitnemal-kompetansebevis-vgs/

Utdanningsdirektoratet. (2021b, 11. januar). Veilederen spesialundervisning. Utdanningsdirektoratet. https:/ / www.udir.no/laring-og-trivsel/sarskiltebehov/spesialundervisning/Spesialundervisning/

Van Maanen, J. (2011). Tales of the field: On writing ethnography. University of Chicago Press.

Widerberg, K. (2007). Institusjonell etnografi: En ny mulighet for kvalitativ forskning. Sosiologi i dag, 37(2), 7-28.

Åsheim, H. (2018). Den institusjonelle utholdenheten. Tidsskrift for velferdsforskning, 21(3), 257-270. https:/ / doi.org/10.18261/issn.2464-3076-2018-03-05 